\title{
The price of trust - a response to Weingart and Guenther
}

\section{Jane Gregory}

\section{Abstract}

Keywords
In response to Weingart and Guenther [2016], this essay explores the issue of trust in science communication by situating it in a wider communications culture and a longer historical period. It argues that the popular scientific culture is a necessary context not only for professional science, but also for the innovation economy. Given that the neutrality of science is a myth, and that science communication is much like any other form of communication, we should not be surprised if, in an innovation economy, science communication has come to resemble public relations, both for science and for science-based innovations. The public can be sceptical of PR, and may mistrust science communication for this reason.

History of public communication of science; Participation and science governance; Public engagement with science and technology

All communication has to be trustworthy to some extent, if it is to achieve any purpose. Communication forges communities, which maintain and identify themselves by talk. Talk establishes common sense and mutual understanding. Most of the time, most people are not mistaken or lying, which helps us get along. We do not think about these everyday exchanges very much. They are subject to what Giddens has called 'civil inattention': to ensure the smooth running of society, we routinely trust all our familiar institutions and relationships, and rarely question or comment on what is happening around us [Giddens, 1990]. Most scientific change is quiet: when we read about science in the news, overwhelmingly we want to consume what it offers. When we question science, such events are so rare and so surprising that they become scandals [Beck, 1992].

Weingart and Guenther [2016] have explored the assertion that not only science but also science communication is losing public trust. They argue that the accessibility of new media, and the broad array of authors they enable, have raised doubts about the credibility of science communication. They also argue that the involvement of nation-states undermines the credibility of science communication. I will add another perspective, but first I note three significant achievements of science studies. We now accept, as a field, that the neutrality of science is a myth. Science is not, and has never been, neutral, and scientists are not disinterested, however hard some practitioners may strive so to be [Shapin, 2008]. The second achievement of science studies is the idea that science communication sits within the social continuum of scientific practice [Collins and Pinch, 1979; Lewenstein, 1995]. The third is that science communication, in any medium, is primarily communication, like any other in that medium, and only in minor ways special or 
different because it is about science [Shinn and Whitley, 1985; Gregory and Miller, 1998; Gregory, 2011]. In this light, then, we have little reason to expect that science communication will be, or has ever been, neutral; but it is not 'tainted' by interests: this would suggest some previous pure state of neutrality, which never was. Science communication is simply interested, as are most, if not all, of our communicative acts. So perhaps it is not surprising that questions about the trustworthiness of science communication are being raised now, when the present era is characterised by a widespread scepticism and an awareness of the grave inequalities that the exercise of private interests has brought about [Beck, 1992; Giddens, 1990; Wagner, 2008].

My vision of science communication's past differs from Weingart and Guenther's, but since science communication embraces a wide range of actors, styles, allegiances, knowledges and interests, there are points where we overlap. Weingart and Guenther refer to science communication emerging as a counterpoint to the new institutionalised, professionalised science of the 19th century; I would argue that its historical roots go deeper than this [Fyfe and Lightman, 2007; Morus, 1998; Stewart, 1992]. There is historical evidence for the public communication of natural knowledge by plural and diverse people that long predates both the formal defining of the word 'science' in its contemporary meaning, and the emergence of the professional scientist. People made money from science communication, in theatres, parlours, marketplaces and fairs, and whether they were trusted or not is a question that we can ask under conditions of historical contingency and cultural relativism, but which is difficult to answer empirically: there was certainly room for charlatans in that world, as there was (and indeed still is) in every sphere of life. In any case, what would these communicators be trusted for? An insight, a cure, a voyage into the sublime [Huang, 2015], or just a good night out? As we know, repeated attempts by the scientific community to license or otherwise control popular science have always failed, which suggests it has autonomy and momentum that are independent of institutionalised science.

These centuries of history give the public communication of natural knowledge, be it mathematics, astronomy, botany, medicine or mechanics, a secure niche in the cultural life of Europe. It is not a by-product of the specialisation of scientists, but the social foundation upon which the specialists found their feet.

I also extend the timeframe of Weingart and Guenther's perspective on science communication and politics. Governments - or 'rulers' at least - also have had a long-standing interest in natural knowledge [Shapin, 2008]. In the classical era, and since the Renaissance, queens, princes, and wealthy elites have hosted expert advisers with special knowledge, in order to encourage manufacture, support expeditions and expansions, and interpret the world. In 1808, Napoleon commissioned a report on the state of the sciences in France from the naturalist Georges Cuvier, who asserted the role of public scientific communication in bringing coherence and efficiency to their disrupted nation [Cuvier, 2011]. Prince Albert, husband to Queen Victoria, inspired and produced one of the greatest spectacles of the nineteenth century, the Great Exhibition, in London, which tied scientific knowledge, technical achievement and spectacular entertainment to the aspirations of the Empire [Auerbach, 1999]. Not only that, but the Great Exhibition was competitive: by drawing together the people and products from around the world, Albert could highlight the strengths and weaknesses of British industry, and 
alert us to rivals elsewhere. So the communication of science for political ends is neither novel, nor unique to our age.

So what is it that raises questions about the trustworthiness of science communication today? This is a live issue among science journalists in Europe, who debated the problems of independence and interests at their 2016 Conference, as they had in 2014 [European Conference of Science Journalists 2016; Autzen, 2014]. One answer to this question, which is particular to our age, now, lies in the acceleration of commercialisation in science, and the transformation this has wrought in science communication. In short, science communication makes money. I am not saying here, like Weingart and Guenther, that 'there is money in the game': I am saying money is the game. Science communication is, in our time, a weapon in the battle for commercial supremacy in the market.

Commercialisation is the dominant theme of U.K. science policy. Scientific knowledge has become a commodity: it is the basic raw material of our age. If we look at the place of science communication in the U.K. government during this time, we can see it under the ministerial labels Culture, in the early 1990s, then Education and Science, then Trade and Industry, and now Business, Industry and Skills. The wider public, who were welcome in science communication as Culture, were progressively marginalised as the focus shifted towards Business [Thorpe and Gregory, 2010]. At same time, public money for science communication research has privileged economically strategic technologies such as biotechnology and nanotechnology (and research begets research) (see table 1). These funding priorities suggest that science communication is being used as a form of governance, and for economic reasons.

Table 1. Despite botany, robotics and cosmology being staples of popular science, the published research in science communication journals shows much greater attention being paid to commercially significant science and technology (searched in August 2016).

\begin{tabular}{|l|l|l|}
\hline \multirow{2}{*}{ Search term } & \multicolumn{2}{|c|}{ Items returned } \\
\cline { 2 - 3 } & Science Communication & Public Understanding of Science \\
\hline Biotechnology & 190 & 410 \\
\hline Chemistry & 125 & 183 \\
\hline Nanotechnology & 121 & 178 \\
\hline Botany & 25 & 34 \\
\hline Robotics & 22 & 13 \\
\hline Cosmology & 14 & 29 \\
\hline
\end{tabular}

Science seems to have cast off the taboo of 'profit' [Shapin, 2008]: it is now a positive attribute in science to be concerned with making things that will sell. The funding of research by corporations, and links between corporations and universities, have blurred the lines between private interests and public knowledge [Bauer and Gregory, 2007].

At the same time, matters of basic science, such as particle physics and space exploration, are also being promoted. The recent news of 'Starshot', a proposed space probe to another galaxy, suggests that there is no limit to what science can do [Ghosh, 2016]. The history of science is littered with such promise; and less so with the outcomes of these ambitious schemes. The protagonists in this particular story 
are two digital entrepreneurs, Mark Zuckerberg and Yuri Milner, and Stephen Hawking, a celebrity scientist.

The important context of these changes is the novel and all-pervasive condition of late capitalism, and the West's innovation economy. An innovation economy should perhaps be called an 'innovation society', as, according to economist Joseph Schumpeter [Jessop, 2002], it relies on an extended network of conditions, resources and attitudes that pervades society: not just on entrepreneurs, and their training and tax-breaks, but also on risk-taking financiers, adaptable manufacturers, spaces for marketing, crafty retailers, enthusiastic consumers and a public that welcomes novelty. (It is worth noting that innovation has not always been seen in a positive light: in seventeenth-century England, innovators risked being seen as at least nefarious, if not heretical and treacherous [Yamamoto, 2011; Godin, 2015].)

In the U.K., the neoliberal turn of the 1980s was fundamental to the pursuit of an innovation economy. It extended market logic to institutions previously understood as public goods, such as hospitals and schools. Science is one such institution, and science is fundamental to the innovation economy, which in turn relies on public acceptance of science. This privatisation of knowledge-production brings with it corporate-style communication [Bauer and Gregory, 2007]. So we have shifted, in science communication, from the logic and values of journalism to the logic and values of corporate communication: that is, media-led activities have been replaced by source-driven reporting of science. At the same time, and despite apparent controversies, our media science has become generally positive about science [Bauer, 2012], even for contested areas such as GM technology [Morse, 2016], which suggests that the advocates have outrun the activists in mobilising the public sphere.

Science communication is very important in an economy committed to innovation, because it provokes, and assists in, the production of the social meanings that bring novel products to life. Communication makes promised innovations real in the social world, sometimes long before they exist (if they ever will). The public contributes (unpaid) work in this innovation economy when they consume, respond to and think about these communications, giving meaning to the proposed new products, and turning them into social and public realities [Thorpe and Gregory, 2010]. These realities should, according to the aims of an innovation economy, exhibit the positive values of the new developments. This kind of science news constructs the public as both workers and customers: it prepares them for the next innovation, by enrolling them in producing it.

The news also contributes to a culture of expectation. The expectations become end-products in themselves, that can be bought and sold as news stories. Very few of these expectations are rewarded with new things in the world, but it is easy to manufacture new expectations to take their place.

How do we ensure positive news? Since the 1980s, there has been a huge growth in the job market for press officers in scientific institutions [Gopfert, 2007]. A good press officer will produce press releases that further his or her employer's interests, and protect it from criticism. There are now in our mass media fewer jobs for independent science journalists, greater corporate control of the journalism that media institutions produce, faster turnaround times, and a greater role for 
advertisers. In this high-pressure context, press releases become an important professional resource for journalists [Granado, 2011; Macnamara, 2015].

This situation is acknowledged in science journalism globally, but it takes on particular significance in our innovation economy. The extensive use of press releases in the production of science news, even by public-interest institutions, brings the values and styles of corporate communication into the mass media. Science news looks and reads like advertising, and not just about the science in question, but also about policy aspects such as the value of science in general, and the need for change. The public notices this: as Hardt and Negri [2000] ${ }^{1}$ argue:

The media have long positioned themselves as the voice or even the conscience of the People in opposition to the power of states and the private interests of capital. ... It has long been clear, however, that the media are in fact often not very independent from capital on the one hand and states on the other.

Thus the values of corporate communications in an innovation economy produce science journalism that furthers private interests. Public relations is misnamed in the sense that it is often not about reaching 'as many people as possible', as Weingart and Guenther assert, but about reaching the people who matter economically: it is often aimed primarily at informing markets and shareholders, rather than empowering, enlightening and activating the public.

We can recognise this new science journalism [Bauer and Gregory, 2007]:

- The tone of the coverage will be celebratory rather than cautious or sceptical;

- Journalists will be reluctant to act as watchdogs;

- The 'events' that confer the 'now' of news need not be real events in the world, but managed events, such as press conferences and journal publications;

- Public debate and controversy will appear all the more unruly compared to the managed politeness of the press conference;

- The ordinary scientist will appear less in the mass media, and instead we will see a few scientific stars and corporate chiefs, who will appear repeatedly (such as the advocates of 'Starshot');

- Our scientific role models will be corporations, not people;

- The public will be treated not as active citizens but as passive consumers; and

- Our public sphere will become a 'shop window' for science.

This co-option of the public sphere for science by commercial interests, within government and without, is the inevitable outcome of ways in which our late-capitalist society and our social relations are structured by the innovation economy. Not only does this process bring the values of the commercial marketplace to the public sphere for science, but it also attracts the mistrust that

\footnotetext{
${ }^{1}$ As examples of scholarship on this point, they offer Said [1981] and Herman and Chomsky [1988].
} 
commercial institutions incur when they prioritise private over public interests. This is a problem for science journalism, but it is not a problem of science journalism: it is problem of global economics. Journalists have an unrivalled set of skills for drawing attention to this problem; however, doing so will jeopardise their employment. It therefore falls to the public to redress the balance between private and public interests, for which task, now, in the 'network society' there is unprecedented potential. According to recent work by Takahashi and Tandoc [2016], public scepticism about science news may already be provoking the public to seek out other sources, so the popular reaction to this attempt to engineer the public sphere for commercial ends may already have started.

\section{References}

Auerbach, J. A. (1999). The Great Exhibition of 1851: A Nation on Display. New Haven, U.S.A.: Yale University Press.

Autzen, C. (2014). 'Press releases - the new trend in science communication'. JCOM 13 (03), C02. URL: https://jcom.sissa.it/archive/13/03/JCOM_1303_2 014_C01/JCOM_1303_2014_C02.

Bauer, M. W. (2012). 'Public Attention to Science 1820-2010 - A 'Longue Durée' Picture'. In: The Sciences' Media Connection - Public Communication and its Repercussions. Ed. by S. Rödder, M. Franzen and P. Weingart. Vol. 28. Sociology of the Sciences Yearbook. Springer, Netherlands, pp. 35-57. DOI: 10.1007/978-94-007-2085-5_3.

Bauer, M. W. and Gregory, J. (2007). ‘PUS Inc.: from journalism to corporate communication in post-War Britain'. In: Journalism, Science and Society: between News and Public Relations. Ed. by M. W. Bauer and M. Bucchi. London, U.K.: Routledge, pp. 33-52.

Beck, U. (1992). Risk Society: Towards a New Modernity. First published in German, 1986. London, U.K.; Thousand Oakes, U.S.A.; New Delhi, India: SAGE Publications.

Collins, H. M. and Pinch, T. (1979). 'The construction of the paranormal: nothing unscientific is happening'. In: On the Margins of Science: The Social Construction of Rejected Knowledge. Ed. by R. Wallis. University of Keele Press, pp. 237-270.

Cuvier, G. (2011). Rapport historique sur les progrès des sciences naturelles depuis 1789, et sur leur état actuel. First published in 1810. Cambridge University Press.

European Conference of Science Journalists (2016). URL: http://www . absw . org. uk/new s-and-events/events/3rd-ecsj-programme.

Fyfe, A. and Lightman, B., eds. (2007). Science in the Marketplace: Nineteenth-Century Sites and Experiences. Chicago, U.S.A.: University of Chicago Press.

Ghosh, P. (12th April 2016). 'Hawking backs interstellar travel project'. BBC News. URL: http://www.bbc.com/news/science-environment-36025706 (visited on 3rd August 2016).

Giddens, A. (1990). The Consequences of Modernity. London, U.K.: Polity Press.

Godin, B. (2015). Innovation Contested: The Idea of Innovation Over the Centuries. Chapter 4. London, U.K.: Routledge. 
Gopfert, W. (2007). 'The strength of PR and the weakness of science journalism'. In: Journalism, Science and Society: between News and Public Relations. Ed. by M. W. Bauer and M. Bucchi. London, U.K.: Routledge, pp. 215-226.

Granado, A. (2011). 'Slaves to journals, serfs to the web: The use of the Internet in newsgathering among European science journalists'. Journalism 12 (7), pp. 794-813. DOI: 10.1177/1464884911412702.

Gregory, J. and Miller, S. (1998). Science in public: communication, culture, and credibility. New York, U.S.A.: Plenum.

Gregory, J. (2011). 'Science communication'. In: The Social Psychology of Communication. Ed. by D. Hook, B. Franks and M. W. Bauer. London, U.K.: Routledge, pp. 300-315. DOI: 10.1057/9780230297616.

Hardt, M. and Negri, A. (2000). Empire. Cambridge, MA, U.S.A. and London, U.K.: Harvard University Press, pp. 311-312.

Herman, E. S. and Chomsky, N. (1988). Manufacturing Consent: The Political Economy of the Mass Media. New York, U.S.A.: Pantheon.

Huang, H. F. (2015). 'Commercial and Sublime: Popular Astronomy Lectures in Nineteenth Century Britain'. Ph.D. Thesis. London, U.K.: University College London.

Jessop, B. (2002). The Future of the Capitalist State. Cambridge, U.K.: Polity Press. Lewenstein, B. V. (1995). 'From Fax to Facts: Communication in the Cold Fusion Saga'. Social Studies of Science 25 (3), pp. 403-436. DOI: $10.1177 / 030631295025003001$.

Macnamara, J. (2015). 'The Continuing Convergence of Journalism and PR: New Insights for Ethical Practice From a Three-Country Study of Senior Practitioners'. Journalism \& Mass Communication Quarterly 93 (1), pp. 118-141. DOI: $10.1177 / 1077699015605803$.

Morse, S. (2016). 'They can read all about it: an analysis of global newspaper reporting of genetically modified crop varieties between 1996 and 2013'. Outlook on Agriculture 45 (1), pp. 7-17. DOI: 10.5367/oa. 2016.0231.

Morus, I. R. (1998). Frankenstein's Children: Electricity, Exhibition and Experiment in Early Nineteenth-Century. London, Princeton: Princeton University Press.

Said, E. W. (1981). Covering Islam: How the Media and the Experts Determine how We See the Rest of the World. New York, U.S.A.: Pantheon.

Shapin, S. (2008). The Scientific Life: A Moral History of a Late-Modern Vocation. Chicago, U.S.A.: Chicago University Press.

Shinn, T. and Whitley, R. P., eds. (1985). Expository Science: Forms and Functions of Popularisation. Vol. 9. Sociology of the Sciences a Yearbook. Dordrecht, Netherlands: Reidel. DOI: 10.1007/978-94-009-5239-3.

Stewart, L. (1992). The rise of public science. Rhetoric, technology, and natural philosophy in Newtonian Britain, 1660-1750. Cambridge, U.K.: Cambridge University Press.

Takahashi, B. and Tandoc, E. C. J. (2016). 'Media sources, credibility, and perceptions of science: Learning about how people learn about science'. Public Understanding of Science 25 (6), pp. 674-690. DOI: 10.1177/0963662515574986.

Thorpe, C. and Gregory, J. (2010). 'Producing the Post-Fordist Public: The Political Economy of Public Engagement with Science'. Science as Culture 19 (3), pp. 273-301. DOI: 10.1080/09505430903194504. 
Wagner, C. (2008). The New Invisible College: Science for Development. Washington, DC, U.S.A.: Brookings Institute Press.

Weingart, P. and Guenther, L. (2016). 'Science communication and the issue of trust'. JCOM 15 (05), C01. URL: http: //jcom.sissa.it/archive/15/05/JCOM_1 505_2016_C00/JCOM_1505_2016_C01.

Yamamoto, K. (2011). 'Piety, Profit and Public Service in the Financial Revolution'. The English Historical Review CXXVI (521), pp. 806-834.

DOI: $10.1093 /$ ehr/cer201.

Author

How to cite

Jane Gregory is an academic working in science communication. In 2015, she launched the MSc in science communication at the University of Manchester. E-mail: janegregoryscicomm@gmail.com.

Gregory, J. (2016). 'The price of trust - a response to Weingart and Guenther'. JCOM 15 (06), Y01. 